\title{
ARTIGOS
}

\section{A RETROSPECTIVE STUDY OF 40 VICTIMS OF CROTALUS SNAKE BITES. ANALYSIS OF THE HEPATIC NECROSIS OBSERVED IN ONE PATIENT.}

\author{
Benedito Barraviera1, José Carlos Bonjorno Junior1, Denlse Arakaki1, \\ Maria Aparecida C. Domingues2, Paulo Camara Marques Perelra1, \\ Rinaldo P. Mendes', Jussara Marcondes Machado' ${ }^{1}$ and Domingos Alves Meira'.
}

\begin{abstract}
Forty patients with a diagnosis of snake bite were studied at the Infectious and Parasitic Disease Service of the Faculty of Medicine of Botucatu. Thirty were males and 10 females, ranging in age from 16 to 70 years. All were farm laborers and 35 of them were bitten in the lower limbs. Two of the 9 patients seen more than 6 hours after the bite died. The low mortality rate (5\%) observed could be explained by the early care provided, by the use of appropriate doses of anti-crotalus serum, parenteral hydration, urine alkalinization with sodium bicarbonate and induction of osmotic diuresis with a mannitol solution. Anatomopathological examination of one of the patients who died revealed extensive hepatic necrosis. The authors discuss the possibility of the effect of a factor of snake venom in the genesis of hepatic necrosis and in the increased transaminase levels.
\end{abstract}

Key-words: Crotalus snake bite. Hepatic necrosis.

Bites by crotalid snakes represent a frequent medical emergency in Brazil and they require the action of properly trained personnel ${ }^{189} 1819212224$. The prevalence of these accidents varies from region to region: $9 \%$ of the snake bite cases seen at Hospital Vital Brasil are due to snakes of the genus Crotalus 2122 , while this frequency reaches $20 \%$ in the Botucatu region 19 . Since crotalid snake bites are usually serious and almost always fatal in the absence of specific and adequate treatment, knowledge about their physiopathology becomes important 82122 .

The venom of these snakes has neurotoxic 78918212226 , hemolytic 2122 and myotoxic 571617 fractions. In severe cases, changes in blood clotting 289182122 and acute respiratory and renal insufficiency 1358910182122 may occur. The latter are the most dreaded complications which usually lead to death of the patient.

In addition to specific treatment with anticrotalus serum, complementary measures are needed to prevent acute renal insufficiency. In view of the

1. Departamento de Moléstias Infecciosas e Parasitárias da Faculdade de Medicina e Departamento de Anatomia Patológica da Faculdade de Medicina de Botucatu - UNESP.

Address: Dr. Benedito Barraviera.

Faculdade de Medicina de Botucatu, UNESP.

CP: 576 - 18610 Botucatu, SP, Brasil.

Recebido para publicação em 13/10/88. present scarcity of serum on the market, of the controversy about dose, complementary treatment standardization and the importance of this topic in the present study we analysed clinical, laboratory and anatomopathological features concerning patients bitten by snakes of the genus Crotalus.

\section{MATERIAL AND METHODS}

Between November 1975 and November 1987, we studied 40 patients with a diagnosis of crotalid snake bite, who were admitted to the Infectious and Parasitic Disease Service of the Faculty of Medicine of Botucatu. Thirty were males and 10 females aged 16 to 70 years. All were farm laborers from the rural zone in the Botucatu region. Thirty five of the patients were bitten in the lower limbs and 5 in the upper limbs. Thirty one were seen within less than 6 hours after the bite and the remaining nine after more than 6 hours.

After clinical evaluation and hospitalisation, all patients were submitted to parenteral hydration with glucose-saline solution induction of osmotic diuresis with $100 \mathrm{ml} 20 \%$ mannitol at 6 -hour intervals for at least 2 days, urine alkalinization with $5 \mathrm{ml} 2 \%$ sodium bicarbonate by the oral route at 6-hour intervals, specific anticrotalus serum therapy, and antitetanus vaccination.

The dose of anticrotalus serum was prescribed on the basis of the severity of each case ${ }^{8} 18$. Twentynine patients who were considered severely affected 

pective study of 40 victims of Crotalus snake bites. Analysis of the hepatic necrosis observed in one patient. Revista da Sociedade Brasileira de Medicina Tropical 22: 5-12, jan-mar, 1989.

received $300 \mathrm{mg}$ of serum or more. The other 11 patients, considered to be moderately affected, received $200 \mathrm{mg}$ of serum. Each patient was first tested for sensitivitv to heterologous serum 818 . When the test was positive, desensitisation was performed as recommended by several authors 9182122 . Clotting time (CT) and serum levels of creatine phosphokinase (CPK), glutamic oxaloacetic transaminase (GOT), creatinine, lactic dehydrogenase (LDH), and calcium $(\mathrm{Ca}++)$ were also determined.

Statistical analysis was performed by the exact Fisher test as described by Siegel 25 .

\section{RESULTS}

The clinical findings obtained when the patients were first examined are given in Table 1 and the results of the laboratory tests performed on the patients are given in Table 2.

Two patients died. Both of them belonged to the group of cases seen 6 hours or more after the bite, whose death rate was significantly higher $(p=0.046)$. A description of these two cases is given below.

Case 1 - VSG, a 60 year old white male bricklayer, married, born in, and coming from Tejupá (State of São Paulo). Date of admission: 11/25/82; data of death: $11 / 29 / 82$.

The patient reported having been bitten in the right leg by a rattlesnake 28 hours before. One hour after the accident he was seen in the township of Piraju (State of São Paulo) where he received $150 \mathrm{mg}$ of anticrotalus serum, parenteral hydration and $500 \mathrm{mg}$ hydrocortisone by the intravenous route. Sixteen hours later he started to show palpebral ptosis, oliguria and dark brown urine. Because of the deteriorating clinical picture, the patient was referred to the University Hospital of the Faculty of Medicine of Botucatu (HCFMB), where he arrived 28 hours after the accident. Physical examination revealed a patient in regular general condition, making good contact and

Table 1 - Distribution of clinical findings in 40 patients bitten by snakes at the time they were first seen.

\begin{tabular}{lcc}
\hline Sign and/or Sympton & Patient \\
& No & $\%$ \\
\hline Pain at the site of the bite & 11 & 27.5 \\
Palpebral ptosis & 10 & 25.0 \\
Diplopia & 10 & 25.0 \\
Edema at the site of the bite & 7 & 17.5 \\
Clouded vision & 6 & 15.0 \\
Myalgia & 3 & 7.5 \\
Respiratory insufficiency & 3 & 7.5 \\
Somnolence & 3 & 7.5 \\
\hline
\end{tabular}

Table 2 - Sensitivity test, clotting time (CT) and serum levels of creatine phosphokinase (CPK), glutamic oxaloacetic transaminase (GOT), creatinine, lactic dehydrogenase ( $\mathrm{LDH})$ and calcium $\left(\mathrm{Ca}^{+}+\right)$in patients bitten by snakes.

\begin{tabular}{lcrrl}
\hline Laboratory test & $\begin{array}{c}\text { Patients } \\
\text { N. }\end{array}$ & $\begin{array}{c}\text { Phowing alterations } \\
\text { N. }\end{array}$ & Alteration \\
\hline Sensitivity test & 40 & 4 & 10.0 & positive \\
CT (minutes) & 16 & 4 & 25.0 & increased \\
CPK $(\mathrm{mIU} / \mathrm{ml})$ & 16 & 16 & 100.0 & increased \\
GOT $(\mathrm{mIU} / \mathrm{ml})$ & 16 & 7 & 43.7 & increased \\
Creatinine $(\mathrm{mg} \%)$ & 17 & 2 & 11.8 & increased \\
LDH $(\mathrm{mIU} / \mathrm{ml})$ & 15 & 7 & 46.6 & increased \\
Ca $++(\mathrm{mg} \%)$ & 8 & 4 & 50.0 & decreased \\
\hline
\end{tabular}


Barraviera B, Bonjorno JrJC, Arakaki D, Domingues MAC, Pereira PCM, Mendes RP, Machado JM, Meira DA. A retrospective study of 40 victims of Crotalus snake bites. Analysis of the hepatic necrosis observed in one patient. Revista da Sociedade Brasileira de Medicina Tropical 22: 5-12, jan-mar, 1989.

with neurotoxic facies. $\mathrm{BP}=150 / 100 \mathrm{mmHg}, \mathrm{P}=$ Pulse $=120 / \mathrm{min}, \mathrm{RR}=28, \mathrm{~T}=36.1^{\circ} \mathrm{C}$. Head: bilateral palpebral ptosis. Neurological examination: somnolent, responding only when asked. Limbs: right leg with $++/+++$ edema and presence of inflammatory signs. At the site of the bite, presence of ulceration covered with a blood stained scab. The patient was treated with $500 \mathrm{ml}$ intravenous physiological saline, $250 \mathrm{ml} 20 \%$ intravenous mannitol, $50 \mathrm{mg}$ intramuscular promethazine, and $200 \mathrm{mg}$ intravenous anticrotalus serum.

The patient was hospitalised and hydrated to promote diuresis. Eight hours after admission he continued to show oliguria ( $0.03 \mathrm{ml}$ per minute), his urine was brown and he did not show diuresis in response to fluid and mannitol infusion. Because of the high central venous pressure in the presence of oliguria, the patient was submitted to restriction of fluids and to a hypercaloric and low-protein diet. Acute renal failure was diagnosed on the same day $(11 / 26 / 82)$. On November 27 , the patient developed generalized edema, anuria and high urea and potassium levels, and peritoneal dialysis was started. On November 29 , his general condition worsened, with the onset of dyspnea and intensification of edema followed by irreversible cardiorespiratory arrest despite attempts at resuscitation.

Table 3 summarize the main results of the laboratory and figures 1 and 2 show the renal and muscle necrosis.

Table 3 - Results of the laboratory tests performed on Case 1

Test

$11 / 26 / 82$

Date

\begin{tabular}{lcccc}
\hline Sodium $(\mathrm{mEq} / 1)$ & 136 & 138 & 131 & 126 \\
Potassium $(\mathrm{mEq} / 1)$ & 3.0 & 6.1 & 5.3 & 4.7 \\
Calcium $(\mathrm{mg} \%)$ & 5.0 & 7.0 & 7.8 & 7.7 \\
Urea $(\mathrm{mg} \%)$ & 67 & 126 & 128 & 119 \\
Creatinine $(\mathrm{mg} \%)$ & - & - & - & 6.3 \\
Proteinuria & ++++ & ++++ & - & ++++ \\
Glycosuria & ++++ & - & - & + \\
\hline
\end{tabular}

* Day on which peritoneal dialysis was started.

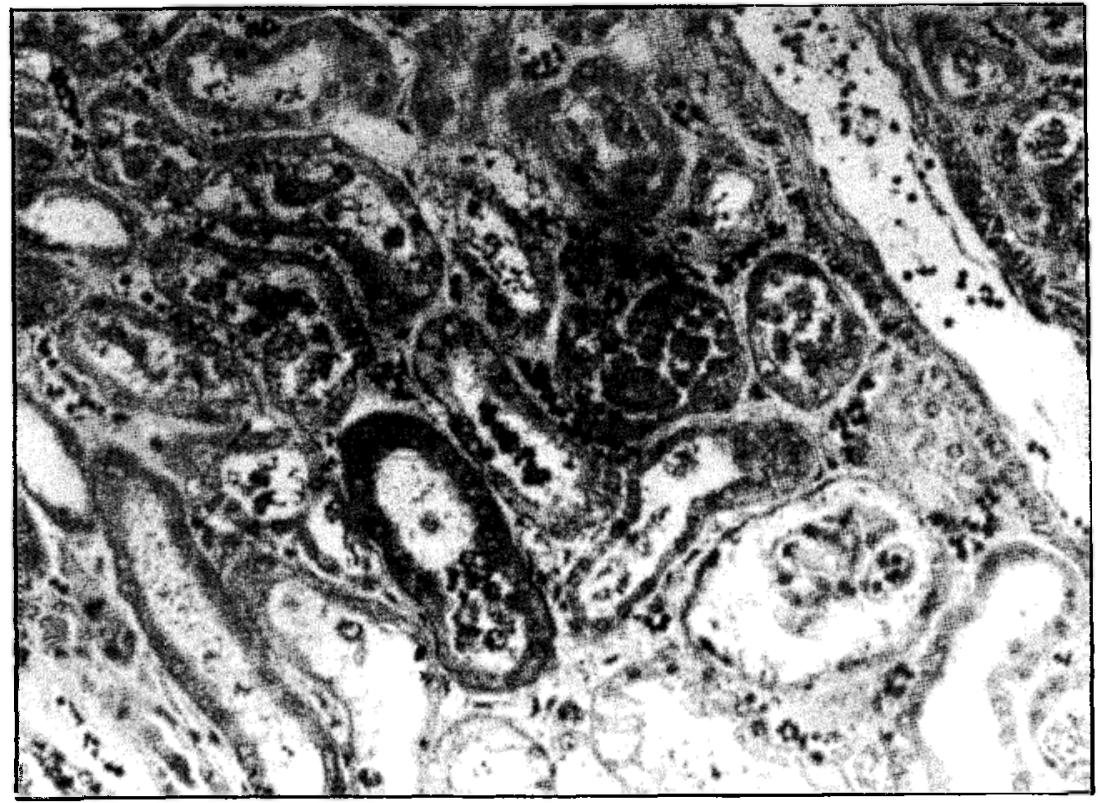

Figure 1-Kidney with acute tubular necrosis. Hematoxylin-eosin (HE) $40 X$. 


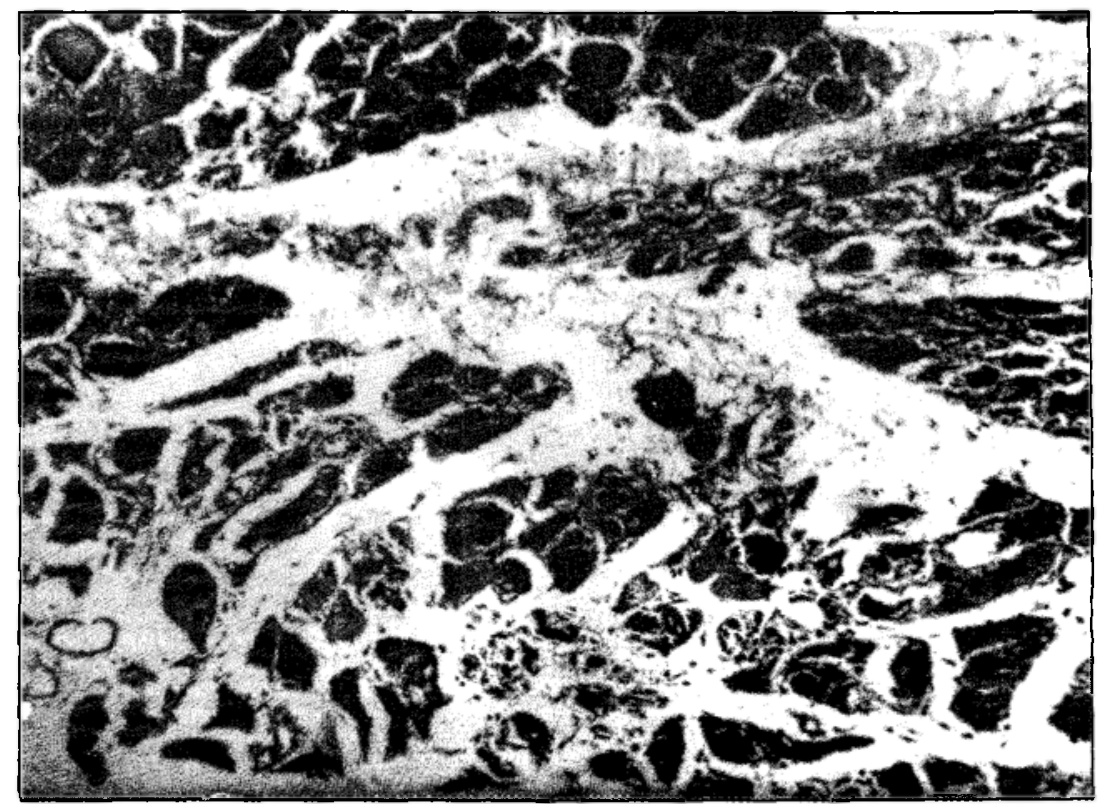

Figure 2-Skeletal muscle with focal myonecrosis at the site of the bite. Hematoxylin-eosin (HE) $40 X$.

Case 2 - AB, a 59-year old white single male, a farm labourer born in Laranjal Paulista (SP) and coming from Tietê (SP). Date of admission: 10/14/87; date of death: $10 / 19 / 87$.

The patient reported having been bitten in the right leg by a rattlesnake. Two hours after the accident he sought medical care in Tietê (SP), where he was medicated with $45 \mathrm{mg}$ anticrotalus serum subcutanemsly. A tourniquet was applied to the affected limb above the site of the bite and the patient was referred to HCFMB, where he was seen 6 hours after the accident. The tourniquet was loosened and the patient received $300 \mathrm{mg}$ of anticrotalus serum by subcutaneous route. Since the test for sensitivity to the serum was positive, desensitization was required. The patient simultaneously received $20 \mathrm{mg}$ promethazine, $1000 \mathrm{ml}$ physiologial saline and $100 \mathrm{ml} 20 \%$ mannitol by intravenous route and was then admitted to the hospital.

The patient still complained of intense generalized headache clouded vision and generalized muscle pains. No report of bleeding. He had been a cigarette smoker for 53 years, was a chronic alcoholic and was an untreated hypertensive.

Physical examination revealed a patient in regular general condition, somnolent, making little contact and with neurotoxic facies. Blood pressure $210 \times 120 \mathrm{mmHg}$, Pulse 100/min., RR $=28 \mathrm{mpm}, \mathrm{T}=$ $36.5^{\circ} \mathrm{C}$. Presence of diplopia and bilateral palpebral ptosis. The right leg showed the presence of two punctiform erythematous lesions with no signs of inflammation.
The patient suffered a hypertensive episode, reaching pressure levels of $300 \times 160 \mathrm{mmHg}$ one hour after admission for which he was treated with sodium nitroprusside. He simultaneously developed edema of the glottis for which he was submitted to emergency tracheostomy. A respiratory arrest followed but was reversed with resuscitation measures. The clotting time test revealed nonclotting blood. On the following day (October 15, 1987) his clotting time was increased and he continued to bleed through his tracheostomy. A decision was made to administer an additional $100 \mathrm{mg}$ of anticrotalus serum subcutaneously. The patient entered into anaphylactic shock which was reversed with adrenalin and promethazine, and then developed metabolic acidosis and hematuria even though diuresis continued to be adequate. Since he showed psychomotor agitation, he was examined by a neurologist who suggested the presence of intracranial hypertension and brain edema. Treatment with hydration and $20 \%$ mannitol at the dose of $100 \mathrm{ml} /$ hour was maintained.

On the following day (October 16, 1987) he developed attacks of apnoea for which artificial ventilation was prescribed, as well as a cardiac arrest that was reversed by resuscitation maneuvers. He then began to show increased serum urea and creatinine levels as well as anemia due to tracheal bleeding. A red blood cell concentrate $(600 \mathrm{ml})$ was administered. On October 17,1987 his general condition worsened, with a marked increase in urea and creatinine levels, and on October 18 his condition progressively worsened, with urea and creatinine levels of 140 and $8.1 \mathrm{mg} \%$, respectively, although diuresis continued to be ade- 
Barraviera B, Bonjorno JrJC, Arakaki D, Domingues MAC, Pereira PCM, Mendes RP, Machado JM, Meira DA. A retrospective study of 40 victims of Crotalus snake bites. Analysis of the hepatic necrosis observed in one patient. Revista da Sociedade Brasileira de Medicina Tropical 22: 5-12, jan-mar, 1989.

quate with no myoglobinuria or hematuria. On the same day, EEG examination showed minimal brain activity and the patient suffered an irreversible cardio- respiratory arrest. Table 4 presents the main results of the laboratory tests and figure 3 shows the liver histology.

Table 4 - Results of the laboratory tests performed on Case 2.

\begin{tabular}{|c|c|c|c|c|}
\hline \multirow[t]{2}{*}{ Test } & \multicolumn{4}{|c|}{ Date } \\
\hline & $10 / 15 / 87$ & $10 / 16 / 87$ & $10 / 17 / 87$ & $10 / 19 / 87$ \\
\hline Hemoglobin (g\%) & 18.1 & 9.0 & 9.5 & 9.0 \\
\hline Sodium (mEq/1) & 137 & 152 & 136 & 144 \\
\hline Potassium (mEq/1) & 4.0 & 4.1 & 4.0 & 3.2 \\
\hline Calcium (mg\%) & 7.6 & 7.5 & 7.6 & 7.6 \\
\hline Urea (mg\%) & 32 & 71 & 98 & 140 \\
\hline Creatinine $(\mathrm{mg} \%)$ & - & 2.5 & 3.7 & 8.1 \\
\hline Proteinuria & $++t$ & +++ & ++ & - \\
\hline Hematuria & ++++ & $+++t$ & ++++ & - \\
\hline Heme-pigment & $+++t$ & $+t+t$ & ++ & - \\
\hline GOT (mIU/ml) & - & 1840 & - & - \\
\hline GPT (mIU/ml) & - & 360 & - & - \\
\hline $\mathrm{LDH}(\mathrm{mIU} / \mathrm{ml})$ & - & 563 & - & - \\
\hline
\end{tabular}

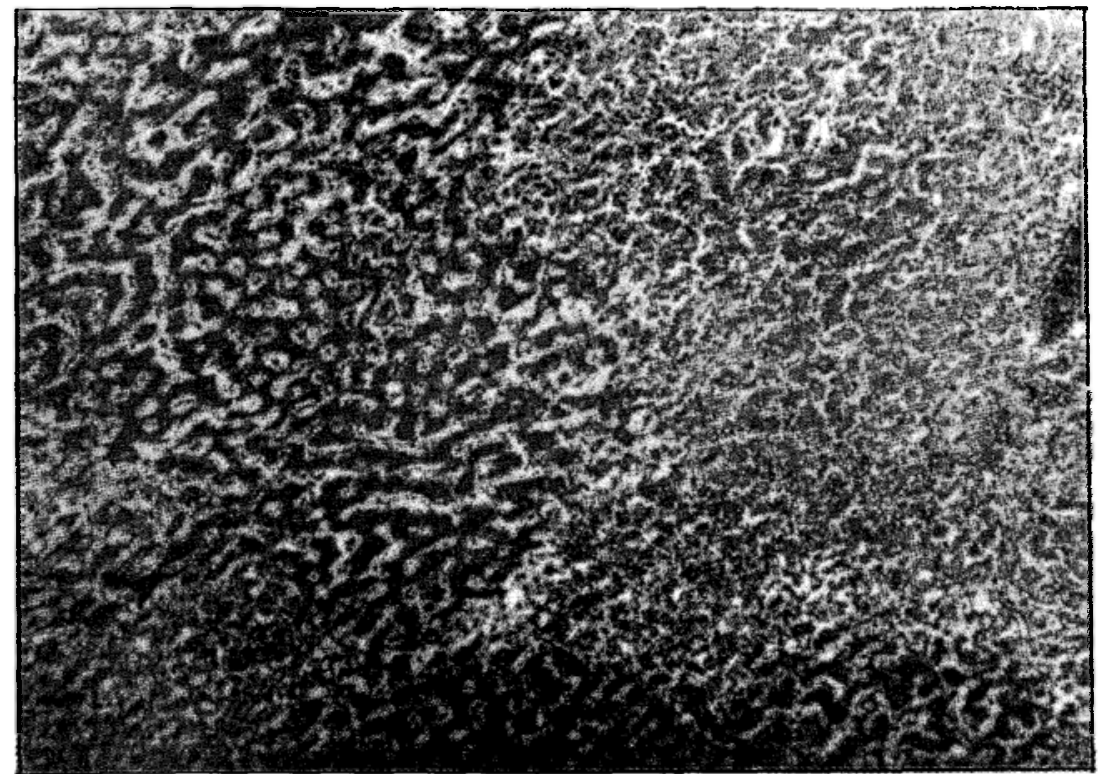

Figure 3-Liver with extensive areas of necrotic parenchyma. Hematoxylin-eosin (HE) $16 X$.

\section{DISCUSSION}

Usually the victims of snake bites are individuals whose profession is related to work in the fields or who visit these places 891822 . Because of the ecology of snakes, these accidents frequently occur in dry, cultivated environments 811182122 . Thus the most common victims are male laborers in their working years. These accidents are considered to be professional accidents since the victims are healthy individuals usually bitten while they work ${ }^{11}$. The lower limbs are most often attacked because Brazilian laborers have not developed the habit of wearing boots 10112122 . In the present study, all individuals were field laborers, most of them adult males, who were almost always bitten in the leg. These results agree with those reported by other authors 1011181922 .

The time elapsing between the accident and medical assistance is a fundamental factor in the evolution and prognosis 89192122 . Thus, patients 
Barraviera B, Bonjorno JrJC, Arakaki D, Domingues MAC, Pereira PCM, Mendes RP, Machado JM, Meira DA. A retrospective study of 40 victims of Crotalus snake bites. Analysis of the hepatic necrosis observed in one patient. Revista da Sociedade Brasileira de Medicina Tropical 22: 5-12, jan-mar, 1989.

seen within the first 6 hours usually show good clinical evolution, as observed in the present study. The only 2 fatal victims were patients seen after 6 hours. These data agree with those reported in other studies which included early medical help as a prognostic factor 18111822 .

The early care given to most of the present patients may justify the presence of the clinical picture observed in only $25 \%$ of cases. It should be pointed out that, since this was a retrospective study, the patient's record may have been filled out in a faulty manner in some cases, so that a clinical picture may have been present in a larger percentage of patients than recorded. If on the one hand early treatment increases the chance of survival, but it is difficult to estimate the amount of serum needed for each case. Because of these difficulties, all patients were submitted to serum therapy at the doses recommended by the manual of the Health Department ${ }^{18}$ and for these reasons the patients were classified as moderately and/or seriously ill.

In addition to specific treatment, the patients also received parenteral hydration and diuresis was induced with a mannitol solution. Mannitol, an excellent osmotic diuretic 27 , is indicated in the prophylaxis of acute renal failure in patients with hemolysis 18 or rhabdomyolysis 51617 . In addition, mannitol reduces brain edema 27 . Since crotalus venom is neurotoxic 26 , brain edema may occur, also due to hyperhydration with physiological saline. In this case, mannitol would be indicated for its action at the kidney and central nervous system level and is the diuretic of first choice in this type of accident 8212227 .

All patients received an oral sodium bicarbonate solution for urine alkalinisation. Metabolic acidosis, dehydration and rhabdomyolysis presdipose to acute renal failure 1317 . Among the patients presented only $1(2.5 \%)$ developed anuria and required peritoneal dialysis. Thus early treatment adequate doses of serum, hydration, urine alkalinisation and the use of an osmotic diuretic contribute significantly to a reduction of mortality.

Clotting time was altered in $25 \%$ of cases. This effect may have been due to conversion of fibrinogen to fibrin by the crotalus venom fraction having a clotting action, as previously demonstrated "in vitro" 2 . These patients are usually in serious condition and require high dose of serum for treatment.

CPK was increased in all patients in whom it was measured. Several authors have demonstrated increased serum levels of the enzymes CPK, LDH, GOT and GTP1 581618 . Serum creatinine was elevated in $12 \%$ of all cases, demonstrating impaired renal function ${ }^{4}$. These data agree with those reported by other authors and confirm the direct or indirect nephrotoxic action of the venom 13589182122 .
Serum calcium levels have frequently been found to be reduced during the oliguric phase of renal insufficiency 17 . Hypocalcemia caused by rhabdomyolysis has been attributed to the deposition of calcium salts at the damaged site in the muscle ${ }^{14} 15$. It should be pointed out that the two patients who died developed hypocalcemia.

The high transaminase levels and the intense hepatic necrosis observed at autopsy in one of the patients lead us to propose a possible hepatotoxic action of the venom. A survey of the literature showed that Bancher et $\mathrm{al}^{7}$, demonstrated the ability of crotalus venom to fix preferentially in nervous and hepatic tissue in mice. In that study, the authors ${ }^{7}$ found that hepatic tissue can fix about 15LD50 of Crotalus durissus terrificus venom per gram of tissue, values higher than those detected for renal and muscle tissue. The authors ${ }^{7}$ concluded that considerable hepatic impairment may occur after rattlesnake bites, perhaps even more extensive than that observed in renal parenchyma.

Saliba et $\mathrm{al}^{23}$, in an experimental study on the effect of crotalus venom on cattle, observed hydropic degeneration, steatosis and hepatic necrosis. Magalhães et al ${ }^{17}$ reported two cases of rattlesnake bites in which serum GOT levels were 670 and $1900 \mathrm{mIU} / \mathrm{ml}$, respectively. In the latter patient, GTP levels were $1350 \mathrm{mIU} / \mathrm{ml}$. Transaminase levels increase when hepatic, cardiac or skeletal muscle damage occurs 1220 , even though an increase in GTP is more specific for damage to the liver ${ }^{20}$, while an increase in GOT reflects cardiac and skeletal muscle necrosis. Thus, the patient observed by Magalhães et al ${ }^{17}$ showed GTP levels compatible with "toxic hepatitis", suggesting that hepatic damage had occurred in this case in addition to rhabdomyolysis. Azevedo Marques et $\mathrm{al}^{5}$ reported on 2 autopsied victims, one of whom showed $9750 \mathrm{mIU} / \mathrm{ml}$ GOT. Anatomopathological examination showed that both patients had hepatic steatosis. According to Sherlock ${ }^{24}$, one of the etiologies of hepatic steatosis is the direct action of toxic agents on hepatic tissue. Thus, it is possible that crotalus venom contributed to the genesis of steatosis in these two cases.

Azevedo Marques et al ${ }^{6}$ recently reported on 3 victims of rattlesnake bites who did not die and who had GOT levels of 610,1520 and $2000 \mathrm{mIU} / \mathrm{ml}$.

On the basis of these considerations, we may postulate that hepatic damage occurs rather frequently though this diagnosis is difficult to confirm. Even if the venom is hepatotoxic, it is difficult to evaluate the extent of liver damage by enzyme measurements, since myonecrosis causes an increase in serum levels of the same enzyme that denote aggression to the liver. On 
Barraviera B, Bonjorno JrJC, Arakaki D, Domingues MAC, Pereira PCM, Mendes RP, Machado JM, Meira DA. A retrospective study of 40 victims of Crotalus snake bites. Analysis of the hepatic necrosis observed in one patient. Revista da Socie dade Brasileira de Medicina Tropical 22: 5-12, jan-mar, 1989

the other hand, in view of the large functional reserve of the liver, clinical evidence of hepatic insufficiency is rare.

We suggest that the hepatic necrosis observed in the present case may have been due to anaphylatic shock caused by the use of serum, even though the hypothesis that chronic alcoholism and a possible action of a hepatotoxic factor in the snake venom which may have contributed to the onset of necrosis can not be ruled out.

In conclusion, we recommend better investigation of possible liver involvement in cases of crotalus snake bites.

\section{RESUMO}

Os autores avaliaram 40 doentes com diagnóstico de acidente crotálico, atendidos no Serviço de Moléstias Infecciosas e Parasitárias da Faculdade de Medicina de Botucatu. Desses, 30 eram do sexo masculino e 10 do feminino, com idades variando entre 16 e 70 anos. Todos eram lavradores e 35 deles foram atingidos nos membros inferiores. A maioria dos doentes (31) foi atendida antes de 6 horas do acidente. Dos 9 que receberam atendimento médico após 6 horas, 2 deles evoluíram para o óbito.

Os resultados observados revelaram que o baixo tndice de mortalidade (5\%) verificado pode eventualmente ser explicado pelo atendimento precoce, uso de doses adequadas de soro anticrotálico, hidratação parenteral, alcalinização da urina com bicarbonato de sódio e indução da diurese osmótica com solução de manitol. O exame anatomopatológico de um dos casos que evoluiu para o óbito apresentou extensa necrose hepática. Os autores discutem a possibilidade de interação entre alcoolismo crônico e a ação eventual de um fator hepatotóxico do veneno da serpente na gênese da necrose hepática e no aumento dos niveis de transaminases. hepática.

Palavras-chaves: Acidente crotálico. Necrose

\section{REFERENCES}

1. Amaral CFS, Rezende NA, Silva OA, Ribeiro MMF, Magalhães RA, Reis RJ, Carneiro JG, Castro JRS. Insuficiência renal aguda secundária e acidentes ofidicos botrópico e crotálico. Análise de 63 casos. Revista do Instituto de Medicina Tropical de São Paulo 28: 220 227, 1986.

2. Amaral CFS, da Silva OA, Lopez M, Pedroso ERP. Afibrinogenemia following snake bite (Crotalus durissus terrificus). American Journal of Tropical Medicine and Hygiene 29: 1453-1455, 1980.
3. Amorim MF, Mello RF, Saliba F. Lesōes renais induzidas experimentalmente no cão pelo veneno crotálico. Memórias do Instituto Butantã 34: 137-157, 1969.

4. Andrade DF. Insuficiência renal aguda. In: Paolucci AA (ed). Nefrologia. Guanabara Koogan, Rio de Janeiro, p. 156-179, 1977.

5. Azevedo Marques MM, Cupo P, Coimbra TM, Hering SE, Rossi MA, Laure CJ. Myonecrosis, myoglobinuria and acute renal failure induced by South American Rattlesnake (Crotalus durissus terrificus) envenomation in Brazil. Toxicon 23: 631-636, 1985.

6. Azevedo Marques MM, Hering SE, Cupo P. Evidence that Crotalus durissus terrificus (South American Rattlesnake) envenomation in humans causes myolysis rather than hemolysis. Toxicon 25: 1163-1168, 1987.

7. Bancher W, Rosa RR, Furlanetto RS. Estudos sobre a fixação eletiva e quantitativa do veneno de Crotalus durissus terrificus nos tecidos nervoso, renal, hepático e muscular de Mus-Musculus Linnaeus, 1758. Memórias do Instituto Butantã 37: 139-148, 1973.

8. Barraviera B. Acidentes por animais peçonhentos. In: Meira DA (ed). Terapêutica de doenças infecciosas e parasitárias, EPUME. Rio de Janeiro, p. 33-41, 1987.

9. Barraviera B, Bonjorno JrJC, Arakaki D, Domingues MAC, Pereira PCM, Mendes RP, Machado JM, Meira DA. Acidentes por serpentes do gênero Crotalus. Avaliação de 40 casos. In: Resumos de XXIV Congresso da Sociedade Brasileira de Medicina Tropical, Manaus, $\mathrm{p}$. 116, 1988.

10. Belluomini HE. Conhecimentos sobre as serpentes brasileiras e medidas de prevenção de acidentes. Revista Brasileira de Saúde Ocupacional 12: 82-96, 1984.

11. Belluomini HE, Wakamatsu CT, Lucas SM, Cardoso JLC. Acidentes do trabalho por animais peçonhentos: estudo retrospectivo dos atendimentos feitos durante o ano de 1983 no Hospital Vital Brazil, Instituto Butantã Secretaria da Saúde - São Paulo. Revista da Sociedade Brasileira de Medicina Tropical 20 (supl.): 54-55, 1987.

12. Boavista Nery AL. Provas funcionais hepáticas. In: Miller O (ed.). Laboratório para o clínico. Atheneu, Rio de Janeiro, p. 209-218, 1977.

13. Bywaters EGL, Stead JK. Production of renal failure following injection of solutions containing myohaemoglobin. Quarterly Journal of Experimental Physiology and Cognate Medical Sciences 33: 53-70, 1944.

14. Gabow PA, Kaehny WD, Kelleher SP. The spectrum of rhabdomyolysis. Medicine 61: 141-152, 1982.

15. Knochel JP. Rhabdomyolysis and myoglobinuria. Annual Review of Medicine 33: 435-443, 1982.

16. Kouyoumdjian JA, Harris JB, Johnson MA. Muscle necrosis caused by the sub-units of crotoxin. Toxicon 24: 575-583, 1986.

17. Magalhães RA, Ribeiro MMF, Rezende NA, Amaral CFS. Rabdomiólise secundária a acidente ofidico crotálico (Crotalus durissus terrificus). Revista do Instituto de Medicina Tropical de Sảo Paulo, 28: 228-233, 1986.

18. Manual de Diagnóstico e Trataniento de Acidentes Ofidicos. Ministério da Saúde, Brasilia, Normas e manuais técnicos, 49 p., 1986.

19. Pereira PCM, Arakaki D, Bonjorno Jr JC, Barraviera B, Machado JM, Mendes RP, Meira DA. Acidentes por 
serpentes venenosas. Estudo clínico-epidemiológico de 196 casos. In: Resumos do XXIV Congresso da Sociedade Brasileira de Medicina Tropical, Manaus, p. 117, 1988.

20. Rodwell VW. General properties of enzymes. In: Martin DW, Mayer PA, Rodwell VW. (ed). Harper's Review of Biochemistry. Lange Medical Publications, Los Altos, Califomia, p. 51-62, 1983.

21. Rosenfeld G. Animais peçonhentos e tóxicos do Brasil. In: Lacaz CS, Baruzzi RG, Siqueira JrW (ed). Introduçào à Geografia Médica do Brasil, EDUSP, São Paulo, p. 430-475, 1972.

22. Rosenfeld G. Acidentes por animais peçonhentos. In: Veronesi R. (ed). Doenças Infecciosas e Parasitárias, Guanabara Koogan, Rio de Janeiro, 7. ed., p. 1067 1079, 1982.

23. Saliba AM, Belluomini HE, Leinz FF. Experimentelle Crotalus-Vergiftung bei Rindern-anatomisch-patholo- gische Studie. Deutsche tierärztliche Wochenschrift 90: 503-546, 1983.

24. Sherlock S. Drugs and the liver. In: Diseases of the liver and biliary system. Blackwell Scientific Publications, London, 7th. edition, p. 304-333, 1985.

25. Siegel S. Estatística nào paramétrica para cièncias do comportamento. 1: ed. Mc Graw Hill, São Paulo, 350p, 1975.

26. Vital Brazil O. Venenos ofidicos neurotóxicos. Revista da Associação Médica Brasileira 26: 212-218, 1980.

27. Weiner IM, Mudge GH. Diuretics and other agents employed in the mobilization of edema fluid. In: Goodman Gilmar A, Goodman LS, Rall TW, Murad F (ed). The pharmacological basis of therapeutics. Mac Millan Publishing Company, New York 7th. edition, p. 887-907, 1985. 